\title{
Turkey and Iran's Nuclear Program
}

\author{
Aylin G. Gürzel, Eyüp Ersoy
}

Ms. Gürzel and Mr. Ersoy are PhD candidates in the Department of International Relations, Bilkent University. She has written for Security Index: Russian Journal of International Security. He is the author of Turkish-Chinese Military Relations: Spinning More, Moving Less (International Strategic Research Organization, 2008).

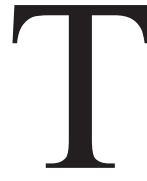

he Nuclear Nonproliferation Treaty (NPT) has suffered serious setbacks since it entered into force in 1970. For example, some nuclear states like Pakistan, India and Israel have refused to sign it. More to the detriment of nonproliferation was the North Korean withdrawal from the NPT and Pyongyang's test of a nuclear device. And Iran's aspiration to produce low enriched uranium (LEU) on its territory has been regarded by the majority of parties involved in the dispute over the Islamic Republic's nuclear program as an intention to build nuclear weapons. This continues to aggravate nonproliferation efforts and adversely affects Middle East politics. Turkish foreign-policy makers, conscious of the actual effects and possible implications of the inauspicious developments over the nuclear dispute, and weary of consequences potentially inimical to Turkish interests, have demonstrated notable diplomatic involvement in the dispute.

Iran's nuclear program continues to be one of the world's most polarized issues. A regional conflagration is a grave possibility, exacerbated by successive estimates of the time frame for Tehran's acquisition of its first nuclear device. The International Institute for Strategic Studies' (IISS) "Dossier on Iran's Nuclear, Chemical and Biological Capabilities" asserts that it may be soon. This report, published in February 2011, is a comprehensive analysis of Iran's quest for dual-use nuclear technologies. The IISS estimates that "it would take Iran at least two years to produce a single nuclear weapon."1

Similar worries are shared by the director of the International Atomic Energy Agency (IAEA), General Yukiya Amano, who reported the agency's concern about the military dimension of the Iranian nuclear program to its Board of Governors on November $8,2011 .^{2}$ This report has revived the debate about Iran's nuclear program. Numerous arms-control and nonproliferation experts have voiced warnings that Iran may follow the North Korean model, which may represent a template for other non-nuclear-weapons countries. Mark Fitzpatrick argues that "the real lesson Iran learned from North Korea is that brinkmanship brings rewards." 3 Through testing a nuclear device, North Korea gained a bargaining chip. It threatened to launch its missile against its adversaries if Middle East Policy (C) 2012, Middle East Policy Council 
Middle East Policy, Vol. XIX, No. 1, Spring 2012

necessary. North Korea has paid no apparent price for withdrawing from the NPT, ${ }^{4}$ leading experts to assume that Iran might well behave in the same manner.

The Turkish concern is that, should the Iranian regime decide to acquire nuclear capabilities, it would be almost impossible to reverse proliferation in the Middle East. Other states would aspire to such capabilities, ${ }^{5}$ the international nuclear nonproliferation regime would come to an end, and regional politics would be destabilized. This runs counter to Turkish diplomacy in the Middle East, which has encouraged stability and order. However, Tehran's insistence on the peaceful nature of its nuclear program has militated against Turkish diplomacy.

Whether Iran intends to build a nuclear weapon or only to generate electricity is a question to be answered before the situation escalates further. Iranian officials in Turkey, such as Farhad Kerimian, maintain that the Iranian nuclear program is solely for the generation of electricity. ${ }^{6}$ However, doubts remain in the international community. There is a widespread conviction that Iran has been misinforming the international community about the issue since 2002, when two unaccounted-for nuclear facilities were discovered in Iran by the IAEA with the assistance of an Iranian opposition group. ${ }^{7}$ At that time, the uranium facility at Natanz was under construction, and the Arak water-production plant had been completed. ${ }^{8}$ The IAEA investigation concluded that Iran had pursued secret uranium enrichment programs for more than a decade and that its "policy of concealment" and "many breaches" of the NPT Safeguard Agreement illustrated that it had not met its treaty obligations. ${ }^{9}$ The latest IAEA report also suggests that there is a military dimension to the Iranian nuclear program.
Ankara's response to the dispute has been the promotion of a non-military multilateral diplomatic solution. This is no selfless act. It typifies "a commitment toward using a multilateral framework as a means to further the interests of the particular state, rather than toward the betterment of the collective group as a whole."10 Turkish policy makers have developed the conviction that the Turkish interests jeopardized by the uneasy dispute over the Iranian nuclear program can best be protected through active Turkish involvement. However, unilateral involvement in so sensitive an issue is certain to be as diplomatically futile and perhaps strategically counterproductive as non-involvement. Accordingly, Turkish diplomacy has been directed towards the promotion of a multilateral settlement. In line with this objective, Turkey has shifted the role it has assumed from observer to facilitator, and from facilitator to mediator.

\section{A CHANGING PERSPECTIVE}

Despite the fact that the Iranian nuclear issue had been a priority on the international agenda since the mid-1990s, Turkey remained indifferent towards it for many years. ${ }^{11}$ It was rarely addressed before 2005, and then Turkey was supportive of Iran's right to develop its own nuclear program. The Justice and Development Party (AKP) leadership has been defending Iran's right to develop peaceful nuclear technolo$\mathrm{gy},{ }^{12}$ a position unequivocally shared by the members of the party. For instance, AKP parliamentarian Ahmet İnal, who served two terms on the board of directors of the parliament's Turkish-Iranian Friendship Committee, stresses Iran's right to advance its nuclear knowledge and technology. ${ }^{13}$ Taking the official party position further, AKP parliamentarian İhsan Arslan argues 
that Iran has every right to acquire nuclear capabilities. ${ }^{14}$ This attitude seems not to be confined to the AKP. Former Minister of State Vehbi Dinçerler, who served under the Motherland Party (ANAP), also states that Iran has the right to "go nuclear." 15

Many factors have led AKP to support Iran's nuclear program, despite its regular statements that militarization of the nuclear program is completely unacceptable. First, energy, in addition to trade, has been an indispensable component of Turkish-IraniThe number of people identifying themselves as Muslim rather than Turkish increased by 10 percent between 2002 and 2007 and continues to increase daily. has stated that, if all obstacles could be removed, the world's 57 Muslim countries as a group would have the potential to be self-sufficient. ${ }^{19}$ This general attitude is not independent of the changing social and political texture of Turkey. Soner Çağaptay asserts that "religion remained the salient national identity during the Ottoman period, ${ }^{20}$ and it is again becoming important, for the population in general and the AKP an relations. As early as July 1996, under Prime Minister Necmettin Erbakan, the two countries signed a $\$ 23$ billion naturalgas deal. Stephen Larrabee affirms that, since then, energy ties between Ankara and Tehran have continued to strengthen. ${ }^{16}$ Still, the current status of bilateral energy ties is unsatisfactory for AKP officials. According to Suat Kınıklığlu, former chief of the AKP foreign-relations committee, the relationship between the two countries needs to be improved in the energy sector, since Turkey imports approximately 12 percent of its natural gas from Iran and cannot afford chilly relations with a potential supplier. ${ }^{17}$ Additionally, "bilateral trade has risen to unpredictable levels, new energy-transportation deals have been made and others have been negotiated." 18

Second, it can be argued that AKP's religious roots have contributed to the country's improved relations with Iran. For Turkish foreign-policy makers, the "Muslim World" in itself is a peculiar geopolitical region in which Turkey can assume a primary role. Prime Minister Erdoğan themselves as Muslim rather than Turkish increased by 10 percent between 2002 and 2007 and continues to increase daily. ${ }^{21} \mathrm{In}$ this sense, as Kibaroğlu observes, "The debate - concerning the Iranian nuclear program - is rather emotional, reactive to daily events, and also partly ideological." ${ }^{22}$

Before 2002, while Turkey was essentially ignoring the Iranian issue, the United States was considering containment measures, and the EU countries were trying to solve the dispute through diplomatic means, adopting an engagement and negotiation strategy. ${ }^{23}$ Russia and China, on the other hand, were improving their ties with Iran, assisting Tehran not only to advance its nuclear program but also to develop its long-range missile technology. After 2002, Turkey's security elite began to grow uneasy about Iran's nuclear and missile programs but still chose not to become involved in attempts at negotiation, preferring to adopt a wait-and-see policy. With the advent of the AKP government, Turkey has shifted from an observer to a facilitator, and then to a mediator. 


\section{FROM OBSERVER TO FACILITATOR}

In 2002, the disclosure of the nuclear facilities at Natanz and Arak undermined the European Union's negotiating approach, bringing the EU closer to sending the issue to the UN Security Council, as the United States had insisted. Thereafter "the emergence of a hardline political leadership in Iran under Mahmoud Ahmedinejad" made the issue more acute, exacerbated by his pugnacious public statements, for example, that Israel should be "wiped off the map." 24

The United States was weighing alternatives that, "alongside rumors, stretch[ed] from imposing various kinds of embargos to unilateral military attack." ${ }^{25}$ Washington continuously urged Turkish officials to cooperate with their Western allies in finding a comprehensive resolution to the problem in conformity with U.S. conditions for a satisfactory settlement of the dispute. With Turkey seeking to restore relations with the United States, which had been seriously damaged over the invasion of Iraq, it was quite challenging for the AKP officials to overlook the U.S. proposition. By 2005, various Turkish government and military officials as well as diplomats had publicly stated their concerns regarding the Iranian nuclear program. Finally, in Turkey's National Security Policy Document of 2005, the Iranian nuclear program was acknowledged as a hot-button issue. ${ }^{26}$

Turkey had tried not to side with the United States or Iran, but the deadlock remained. If an aggressive approach of containment and isolation was instigated by Washington, it would force Turkey to choose between the parties. Turkish officials were concerned that, as had happened with the U.S. invasion of Iraq, a military confrontation between the United States and Iran would adversely affect the region's stability and security. ${ }^{27}$ This apprehension induced Turkey to abandon its observer role and become a facilitator. Iranian policy makers agreed to Turkey's facilitating role so long as Turkey seemed favorable to Iran's position, as an Iranian official in Turkey openly admitted. ${ }^{28}$ Helping the parties reach a settlement through negotiations would liberate Turkey from its difficult balancing act and likely preclude military conflict and the isolation of Iran through a unilateral embargo by the United States or multilateral sanctions by the Security Council. Turkish efforts failed, however, to bring about the desired outcome. Still, Turkish expectations persisted.

\section{FROM FACILITATOR TO MEDIATOR}

In late 2008, Turkey's stance with respect to the Iranian nuclear issue changed once again. After an official visit to the United States, Erdogan proclaimed that Turkey could mediate between Iran and the United States based on its earlier experience of negotiating with Iran. ${ }^{29}$ U.S. Secretary of State Hillary Clinton "embraced Turkey's bid for the mediator position" 30 and announced that the Obama administration would request Turkey's assistance to engage with Iran on the unresolved dispute. Mohamed ElBaradei, then the IAEA director general, also asked for Turkey's diplomatic support to convince Iran to return to the table. Having concluded that Turkey's interests would be well served by responding favorably to these calls, Ankara began exchanging messages with Iranian officials and sending Turkish diplomats to Tehran. Nonetheless, Turkish officials had a difficult time persuading their Iranian counterparts to resume negotiations. Namik Tan, Turkish ambassador to the United States, noted that it was "the Persians who 
invented the game of chess - it took two 18-hour days to get their cooperation." 31

In the end, in October 2009, a uranium fuel-swap agreement between the $5+1$ countries (the Security Council plus Germany) and Iran was discussed in Vienna. ElBaradei proposed placing Iran's lowenriched uranium (LEU) in Turkey's custody in exchange for the Vienna Group's supplying Iran with LEU for the production of electricity. The proposal was accepted by Turkey, Russia and the United

States. After a letter from President Obama to Erdogan about it in October 2009, Turkey continued to try to bring Iran on board.

In May 2010, Iran agreed to have its uranium enriched in Turkey. Turkey and Brazil, the non-permanent members of the Security Council at the time, had negotiated the deal with $\operatorname{Iran}^{32}$ as the Security Council was about to vote on a sanctions package. Jim Walsh notes that, from October 2009 to April 2010, Iranian officials had stalled, not wanting to give up their uranium. When they received the intelligence that Russia and China were going to vote in favor of the sanctions, however, they decided to sign, though reluctantly. ${ }^{33}$ Despite Tehran's decision to abide by the agreement, the Security Council expressed its disapproval, because the deal did not address the issue of LEU produced during the time between the two deals, 20 percent of which would remain in Iran. ${ }^{34}$ The deal was considered only "a tactical move on Iran's part, to illustrate that it was willing to use its nuclear material for peaceful purposes. ${ }^{\prime 35}$ Accordingly, three days later, a new round of UN sanctions was leveled against Iran. ${ }^{36}$ Frustrated, Turkey voted against the sanctions, claiming it would lose credibility otherwise. ${ }^{37}$

Turkish Foreign Minister Ahmet Davutoglu claimed that the Vienna Group's rejection of the swap deal denied Iran's right to produce even peaceful nuclear energy, while continuing to ignore rumors of Israeli nuclear weapons. Israel is not part of the NPT, and although it has not tested a nuclear device or a weapon, it is assumed to have them. ${ }^{38}$ The AKP government not only criticized Israel's nuclear arsenal, but also the "U.S. tacit approval of it." ${ }^{39}$ The common conviction in Turkish public opinion was that the Western countries hesitated to "recognize Iran's right to develop peaceful nuclear energy because they wish[ed] to maintain their monopoly of nuclear energy." ${ }^{40}$ Public "reaction to the Western countries reflected Turkish officials' disappointment with U.S. and European officials, who had encouraged Turkey to persuade Iran to compromise over the swap agreement." ${ }^{41}$ However, officials from the Turkish Foreign Ministry acknowledge that the lack of coordination between Ankara and Washington during the negotiation process ${ }^{42}$ would have contributed to the negative outcome.

In April 2011 in Istanbul, Turkey once again tried to mediate multilateral talks on Iran's nuclear program. During the meetings, EU High Representative of Foreign Affairs Catherine Ashton presented the 5+1 
Middle East Policy, Vol. XIX, No. 1, Spring 2012

countries' plan to improve the transparency of the Iranian nuclear program. Included was an updated version of the uranium fuel-exchange agreement. Iranian officials came to the meeting with two preconditions. First, they requested that the Security Council lift its sanctions before the negotiation process started. This request was, not surprisingly, denied. Further, the Security Council had selected a panel of specialists in November 2010 to evaluate the repercussions of the sanctions to determine whether to strengthen them. Iran was likely expecting to capitalize on the reluctance of Russia and China to take part in the sanctions, but this approach failed.

Iran's second condition was that the United Nations acknowledge Iran's right to make LEU on its territory, one of its constant refrains. Article IV of the NPT acknowledges the right of a state to "use nuclear energy for peaceful purposes," on the condition that it remain transparent about its nuclear program and not engage in proliferation. However, the international community was convinced that Iran had continually violated these commitments. This conviction was affirmed in April 2011, when Tehran verified that it had been constructing uranium-enrichment centrifuge parts at the Taba plant. ${ }^{43}$

Despite this disclosure, Iran continues to argue that it has not violated the NPT. Iran's ambassador to the Netherlands, Kazim Gharib Abadi, argues that "all nuclear activities are under direct supervision of the IAEA, and there has not been any kind of diversion to non-peaceful purposes. You cannot find any report or acknowledgement on behalf of the IAEA that Iran has a nuclear-weapons program." ${ }^{44}$ Despite the many IAEA documents on Iran's misinforming of the IAEA, Iranian officials still claim full cooperation with the agency.
The Istanbul meeting was regarded as a historic opportunity by both the Iranian and Turkish officials as well as academics, ${ }^{45}$ but it ended inconclusively. Several observers had anticipated such an outcome. Henri J. Barkey, for example, affirms that "both sides are playing a game in which the object is to pretend to the audience — the rest of the world - that they mean well." ${ }^{46}$ Many experts have since argued that the intention of Iranian policy makers was to buy time by feigning optimism.

Tehran's alleged insincerity may have resulted from the continuing covert activities against Iran's nuclear program and the unceasing warnings from the international community. The IISS report, for instance, concludes that it would take Iran at least two years to produce a single nuclear device, matching American assessments of the time frame and offering a detailed technical analysis of the situation. On the other hand, industrial sabotage attempts have somewhat decelerated the progression of Iran's nuclear program. ${ }^{47}$ In November 2010, the Iranian government acknowledged that the Stuxnet computer worm had infected some centrifuges, and, in December, the IAEA inspectors confirmed that 984 of Iran's centrifuges had been taken offline. Gholamreza Jalali, Iran's passivedefense-system director, said that Stuxnet "still posed a potential risk... and that [a] new virus, named 'Stars,' was being investigated." ${ }^{48}$ Simply put, there is a cyber war targeting Iran's nuclear program.

Although there is still time for the parties to continue confidence-building measures and to pursue a diplomatic resolution to the dispute, the latest IAEA report has raised further questions in the international community by fomenting the concern that the Iranian program actually has a military dimension. There is the widespread opin- 
ion among Turkish policy makers that Tehran is only trying to buy time and exploit AKP good will. ${ }^{49}$ Former AKP parliamentarian Murat Mercan, the former president of the Council of European Parliamentary Assembly (PACE), asserts that during his negotiations with Iranian officials such as Ali Larijani, speaker of the Majles, and Alaeddin Boroujerdi, chairman of the committee on foreign policy and security, they did not inspire him with confidence. Mercan claims that Shiite Muslims have a very different threat

Turkey's involvement in the Iranian nuclear program is yet another attempt to actualize "strategic autonomy" through the augmentation of its problem-solving capacity and the demonstration of its problem-solving ability. with Russia, bolster economic and security ties with Tehran, create cooperation schemes in the surrounding regions, and normalize political relations with neighbors were the most indicative manifestations of the new thinking." 52 We argue that, in congruence with its proactive foreign policy, Turkey's involvement in the Iranian nuclear program is yet another attempt to actualize "strategic autonomy" through the perspective and that their culture, history and society make it hard to reach a mutually acceptable solution with them. ${ }^{50}$

\section{FAILURE OF APPEASEMENT}

The transformation of the roles Turkey has assumed in its diplomacy over the Iranian nuclear program can be explained with reference to the Turkish interests jeopardized by the dispute. While Turkey's security policy is adversely affected, its economic interests, especially commercial activities with and in Iran, have become increasingly vulnerable.

Nevertheless, the shift in Turkey's roles from observer to facilitator and then mediator can only be partially explained with reference to Turkish interests. This shift is also about Turkey's quest for strategic autonomy in foreign policy. As Şaban Kardaş has argued, "At the core of Turkey's regional policy has been its leaders' ceaseless search for strategic autonomy." 51 To Kardaş, "Ankara's efforts to develop a nascent multi-dimensional partnership ish policy makers, possessing the capacity to solve problems in the neighborhood and demonstrating the ability to do so bespeaks autonomy in foreign policy, an indication of great-power status. The shift in Turkey's role fits the general pattern of diplomatic mediation efforts. Still, the larger purpose is to demonstrate strategic autonomy.

Turkey's contribution to finding a final settlement to the Iranian dispute palatable to all the parties has failed to yield a satisfactory result thus far. For one thing, it seems that Ankara has yet to appreciate the significance of the way it is perceived. Despite not being a party to the dispute, Turkey is not insulated from repercussions of the developments over it. This gives Turkey a vested interest in its settlement or continuation. As a corollary, Ankara's impartiality in its efforts to mediate nuclear negotiations for an acceptable settlement becomes questionable, no matter how much Turkish policy makers insist otherwise. In addition, Ankara's policy of "dual appeasement" in its involvement in Iran's 
nuclear program has been futile. This is mainly due to the fact that success is only possible when the parties voluntarily refrain from escalation during negotiations. Turkey does not possess enough leverage over the parties to dissuade them from taking escalatory actions.

Finally, a policy of dual appeasement is certain to fail if a mediator experiences its own problems with one of the parties. Ankara's relations with Tehran have been plagued by several problems that have militated against its diplomacy. First, the changing dynamics in the Middle East as a result of the Arab Spring and Turkey's decision to be part of NATO's missile-defense system have had repercussions. The Arab Spring has eroded relations between Ankara and Tehran. Events in Syria, in particular, seem to have created new rifts between Turkey and Iran. The fall of the Asad regime would weaken the influence of Tehran in Syria and possibly in Lebanon, leading to Iran's eventual isolation in the region. Such a diplomatic retreat is likely to be exploited by Ankara.

Second, Turkey and Iran are neighbors to Iraq. The two regional powers are still competing for influence in that strategic country, ${ }^{53}$ despite the fact that they have been cooperating in fields like counterterrorism, drug trafficking and stability promotion. However, in the wake of the U.S. troop withdrawal, Turkey and Iran are competing to fill the power vacuum. ${ }^{54}$

Third, Turkey's decision to be part of the missile-defense architecture deployed by NATO has caused notable friction between Ankara and Tehran. Even though, in 2007, Turkey began seeking to develop its own national missile-defense program, ${ }^{55}$ the recent decision has created rifts between the two. Iran has apparently forgotten that Turkey agreed to become part of
NATO's missile-defense system ${ }^{56}$ only after lengthy negotiations and that Turkey insisted on not naming Iran as a threat in NATO's Strategic Concept, adopted in Lisbon on November 19, 2010. ${ }^{57}$

Moreover, although Turkey voted against the Security Council resolution that adopted sanctions on Iran in July 2010, Iran is still concerned with the agreement Turkey signed with the United States to station U.S. missile-defense radar in Kurecik, some 700 kilometers (435 miles) west of the Iranian border. Turkish policy makers such as AKP parliamentarian Hasan Fehmi Kinay were quick to point out that this radar was already in use and thus is just going to restart functioning. ${ }^{58}$ The Turkish government has tried not to create a rift with Iran on this issue. However, President Ahmadinejad has asserted that "the defense system was meant to protect Israel against Iranian missile attacks in the event a war breaks out with the Jewish state." 59 In additioin, and causing a high degree of indignation in Turkey, General Amir Ali Hajizadeh has declared that "if any threat is staged against Iran, we will target NATO's missile shield in Turkey and will then attack other targets." ${ }^{\prime 60}$

\section{A MULTILATERAL APPROACH}

For Turkey to be an effective mediator between its Western allies and Iran, a precondition is Tehran's genuine desire to engage in dialogue with the $5+1$ states. So far, despite numerous attempts, Tehran has not given an impression of such willingness. As William Tobey states, the proposals "seem to have done more to highlight Iran's intransigence than to resolve the issue." ${ }^{61}$ In contrast to the Bush administration, which categorically rejected dialogue with Iran and sought to isolate the regime, the Obama administration has at 
least expressed interest in a dialogue. The Erdogan government has tried to contribute to the effort to find a solution, largely without success. But there is still hope for a possible solution, depending on Tehran's readiness to reach a compromise by agreeing to supply its energy needs from an international uranium fuel center.

Iran can get out of all agreements with reference to a legal framework that it can produce LEU on its own territory for peaceful purposes. This prolongs the suspicion that Tehran is using its right to produce electricity for civilian use as a way to develop a nuclear capability while at the same time developing ballistic missiles with increasing range. One can reach certain conclusions about Tehran's actions, but it is important to note that "the Iranian government is not a unified monolith but a conglomerate of various factions with differing interests and views." ${ }^{62}$

Those within the Iranian government who are open to dialogue with the $5+1$ are apparently too politically weak for their views to gain acceptance. Furthermore, experts are divided over whether regime change in their favor is likely. ${ }^{63}$ Not only is the supreme leader's authority being challenged, but the principles of velayat-e faqih are being questioned. It is probable that divisions in the Iranian leadership will open up against the background of the Arab Spring. But power is still in the hands of more militant and hardline factions.

Larrabee contends that "the Iranian leadership does not want to see any reconciliation with the United States: it would weaken their power and ability to maintain their political influence." ${ }^{\circ 4}$ How can Turkey help resolve this controversial issue under these conditions? The Turkish government has tried to use its relationship with key figures in the Iranian power structure to work on a solution. ${ }^{65}$ However, Turkish officials could not come up with a deal acceptable to the international community unilaterally or with Brazil. In the long run, instead of continuing its efforts to mediate between the parties, one option for Turkey

is to encourage Iran to participate in international nuclear-fuel centers. Participating in Russian and American low-enriched stockpiles as well as the IAEA fuel bank and the UK enriched bond scheme, accepted by the IAEA Board of Governors in March 2011, ${ }^{66}$ will probably constitute enough nuclear fuel for global use, including that of Iran. ${ }^{67}$

If Iran is pursuing enrichment as a reliable source of reactor fuel, an international nuclear-fuel center would guarantee that the transportation of Russian supplies to Iran and other countries in need of LEU would not be interrupted. If Iran's real objective is to construct a nuclear bomb, it will either reject the idea or only agree to it if the facility is located on Iranian territory, where, as William H. Tobey underlines, it would probably continue to provide a latent capacity. ${ }^{68}$ Nevertheless, it would be difficult for Ankara to convince Tehran to agree to the international nuclear-fuelcenters idea. ${ }^{69}$ "The discussion of the state of the (extremely longstanding and complicated) international debate on fuel banks 
Middle East Policy, Vol. XIX, No. 1, Spring 2012

and other variations on these themes is not easily accomplished." ${ }^{\text {70 }}$ Hans Blix, former director of the IAEA, asserts that the least difficult path would be "states in a region themselves taking the initiative" to develop a fuel bank. ${ }^{71}$ Outside initiatives risk being received as pressure from the nuclear states.

However, Alexander Sotnichenko of St. Petersburg University says that the idea of an international fuel center is "captivating" and that the Russian government has been supporting this multilateral approach since $2006 .{ }^{72}$ American experts also support the idea of international fuel centers. For Siegfried S. Hecker of Stanford University, "The world will have to move in this direction to limit the number of fuel cycle facilities and increase their transparency." 73

The issue of centralized international handling of nuclear fuel has previously been explored from the technical and economical aspects, always with a concern for nonproliferation - but it has never been implemented. "It is most reasonable to raise it again in this context." challenge, also for Turkish efforts, would be to convince countries in the developing world that international fuel-cycle development would not result in their dependence on the major powers for nuclear fuel.

Therefore, Charles D. Ferguson states, "A multinational fuel facility may be built in a Middle Eastern country or some country in the developing world in order to show that these states have access to the fuel cycle in that part of the world." 75 In attempts to resolve Iran's nuclear issue, "persistence and creativity are clearly needed." 76

Notwithstanding its increased involvement in the Iranian nuclear dispute, Turkey's attempts to resolve the issue have been unsuccessful so far. Foreign Minister Davutoglu is willing to perform whatever role Turkey ought to assume to resolve this matter. However, one can argue that, if mediation is to no avail, after a time it can be regarded as futile. The impression that the Turkish government's mediation efforts have been misused by the Iranian regime just to buy time has not completely vanished. Economic sanctions, on the other hand, are discussed critically by Turkish policy makers, since Ankara maintains a desire to improve its economic relations with Iran. Yet, sanctions can only work if they are applied everywhere. Therefore, Turkey may need to consider joining the international efforts.

Some observers, politicians and scholars alike, still view Turkey as an advocate of Iran. Elliot Abrams argues that, if Turkey wants to help resolve the issue in the short term "[i]t should stand firmly behind [the] UN Security Council as well as the IAEA resolutions and urge Iran to comply with them." 77 Anything else, from the perspective of these observers, will diminish international unity and allow the Iranian regime to buy time. Gunter Verheugen, the former European commissioner, also asserts that "the recent IAEA report is alarming, and something needs to be done," 78 arguing that the best option is for Ankara to join the multilateral efforts.

It is quite understandable that the AKP leadership does not want to increase the instability of the region and is still trying to help solve the Iranian nuclear dispute by advocating dialogue and performing facilitation and mediation. This is, of course, the preferable option. Exhibiting a degree of extreme optimism, AKP parliamentarians such as Dr. Idris Bal and Hasan Fehmi Kinay, as well as the chief of the Turkish Parliament Commission, Volkan Bozkır, still believe that the Iranian nuclear program is for peaceful purposes. They argue that Tehran has the right to produce 
nuclear energy and to possess nuclear technology, even though there is some criticism among AKP politicians that the Iranian regime does not appreciate Turkish efforts to support Iran's nuclear program. AKP parliamentarians add that nuclear technology should not be monopolized by nuclear-weapons states.

In terms of Ankara's relations with the other party to the dispute, it is asserted that President Obama and Prime Minister Erdogan have been in close contact since January 2011. Soner Çağaptay indicates that President Obama and Prime Minister Erdogan give great importance to constant consultations and are trying to be in close cooperation through direct telephone discussions. ${ }^{79}$ The failure of the nuclear-swap agreement may actually have led the two governments into full coordination, so that another attempt will not fail.

The Turkish government, on the other hand, seems to underestimate the possibility that the Israeli government may decide to strike Iran's nuclear facilities. ${ }^{80}$ Foreign Minister Davutoglu has consistently refused to discuss such an option. By the same token, Gürsel Demirok, a retired Turkish diplomat and the director-in-chief of research and development at the Turkish National Security Council, does not think the IAEA report will change the Turkish position. Demirok reaffirms that Turkey's attempts to resolve the issue have been unsuccessful so far, but is still optimistic that Turkey can facilitate dialogue between Iran and the international community by mediation.

Turkey will never return to being an observer. Its involvement with the Iranian nuclear program is yet another attempt to actualize "strategic autonomy" by augmenting its problem-solving capacity. To Turkish policy makers, being able to solve problems in the vicinity of Turkey bespeaks autonomy in its foreign policy, an indication of great-power status. As the reasoning goes, no problem in the geostrategic area identified with Turkey can be solved without Turkish involvement. In order to reach such strategic autonomy, however, Turkey has to prove it can settle disputes in its vicinity, the major one being that of Iranian nuclear capabilities.

\footnotetext{
${ }^{1}$ International Institute for Strategic Studies (IISS), “Iran's Nuclear, Chemical and Biological Capabilities — A Net Assessment," News Release, February 3, 2011, http://www.iiss.org/publications/strategic-dossiers/ irans-nuclear-chemical-and-biological-capabilities/press-statement/.

${ }^{2}$ Report by the International Atomic Energy Agency (IAEA) Director General Yukiya Amano, "Implementation of the NPT Safeguards Agreement and Relevant Provisions of Security Council Resolutions in the Islamic Republic of Iran," GOV/2011/65, November 8, 2011. A large volume of documentation is listed in the report - correspondence, reports, view graphs from presentations, videos and engineering drawings - amounting to over a thousand pages. The information reflected in that documentation is of a technically complex and interconnected nature, showing research, development and testing activities over time. It also contains working-level correspondence consistent with the day-to-day implementation of a formal program. ${ }^{3}$ Mark Fitzpatrick, “Assessing Iran's Nuclear Program,” Survival 48, no. 3 (Autumn 2006).

${ }^{4}$ The Treaty for the Nonproliferation of Nuclear Weapons, better known as the Nuclear Nonproliferation Treaty (NPT), was signed on July 1, 1968, by the United States, Soviet Union, United Kingdom, and 59 other countries. It came into force on March 1, 1970. Currently, 189 are party to the treaty and it has evolved into an
} 
Middle East Policy, Vol. XIX, No. 1, Spring 2012

international nuclear nonproliferation regime. See "NPT Treaty," http://www.u-s-history.com/pages/h1807.html. ${ }^{5}$ Mustafa Kibaroğlu, "Iran's Nuclear Program May Trigger the Young Turks to Think Nuclear," Carnegie Endowment for International Peace, http://www.ceip.org.

${ }^{6}$ Farhad Karimian (Counselor of the Iranian Embassy, Ankara Turkey), interview, March 2011.

${ }^{7}$ Greg Bruno, "Iran's Nuclear Program," Council on Foreign Relations, March 2010.

${ }^{8}$ Peter Crail, "Questions Surround Iran's Nuclear Program," Arms Control Today, http://www.armscontrol. org/factsheets/Iran-IAEA-Issues. For more up-to-date information, including satellite imagery of some of the facilities in Iran, visit http://www.globalsecurity.org.

9 John S. Wolf, "NPT Articles I and II," Assistant Secretary for Nonproliferation, Alternate Representative of the United States of America, Third Session of the Preparatory Committee for the 2005 Review Conference of the Treaty on the Nonproliferation of Nuclear Weapons (U.S. Department of State, New York City, New York, April 30, 2004).

${ }^{10}$ Qunyh-Nhu Vuong, "U.S. Peacekeeping and Nation-Building: The Evolution of Self-Interested Multilateralism," Journal of International Law 21, no. 1 (2003): 805.

${ }^{11}$ Panel at Middle East Technical University (METU), "Turkish-Japanese Perspective towards the Middle East” (Bayram Sinkaya, Ankara Turkey, November 23, 2010).

${ }^{12}$ Özgür Özdamar and Nihat Ali Özcan, "Uneasy Neighbors: Turkish-Iranian Relations since the 1979 Islamic Revolution," Middle East Policy 17, no. 3 (Fall 2010): 114.

${ }^{13}$ Ahmet Inal (former member of the board of directors for the Turkish-Iranian Friendship Committee of the Turkish Parliament, AKP, Batman, TBMM, Ankara, Turkey), October, 2010.

${ }^{14}$ Bayram Sinkaya (Middle East Technical University, Ankara, Turkey), personal interview, November 8, 2010.

${ }^{15}$ Vehbi Dinçerler (former minister of state, Motherland Party ANAP), in discussion with the author, May 2011.

${ }^{16}$ Stephen F. Larrabee, Turkey As a U.S. Security Partner (RAND, 2008), 12.

${ }^{17}$ Suat Kiniklioglu (former Justice and Development Party Foreign Relations Committee member, Deputy Prime Minister's Office and chairman of the board of directors for the Turkish-American Friendship Committee, Çankırı, TBMM, Ankara, Turkey), September 2010.

${ }^{18}$ Özgür Özdamar and Nihat Ali Özcan, "Uneasy Neighbors": 112.

${ }^{19}$ Cüneyt Ülsever, "Hayal ile gerçek arasında: 'Biz bize yeteriz'," Hürriyet, January 5, 2011.

${ }^{20}$ Soner Çağaptay, “The AKP's Foreign Policy: The Misnomer of 'Neo-Ottomanism'," Changing Turkey, December 15, 2009. See also Soner Çağaptay, “Is Turkey Leaving the West?” Foreign Affairs, October 26, 2009.

${ }^{21}$ Soner Çağaptay, "Sultan of the Muslim World," Foreign Affairs, November 15, 2010.

${ }^{22}$ Mustafa Kibaroglu, “Turkish Perspectives on Iran's Nuclearization,” Eurasian Critic, April, 2009, http:// www.eurasiacritic.com/articles/turkish-perspectives-iran $\% \mathrm{E} 2 \% 80 \% 99 \mathrm{~s}$-nuclearization.

${ }^{23}$ Bayram Sinkaya (Middle East Technical University, Ankara, Turkey), in discussion with the author, November 8, 2010.

${ }^{24}$ Nazila Fathi, “Wipe Israel 'Off the Map' Iranians Say,” New York Times, October 27, 2005, http://www. nytimes.com/2005/10/26/world/africa/26iht-iran.html.

25 “Is Washington Planning a Military Strike," Der Speigel, December 31, 2005, http://www.iran-press-service.com/ips/articles-2005/december-2005/us_attack_iran_311205.shtml.

${ }^{26}$ Duygu Güvenç, “12 Mil Artik Savaş Nedeni Değil,” Sabah, August 23, 2011.

${ }^{27}$ Interview with high-ranking Turkish diplomat, October 26, 2010.

${ }^{28}$ Farhad Karimian (counselor of the Iranian Embassy, Ankara, Turkey), in discussion with the author, March $14,2011$.

${ }^{29}$ Hürriyet, "Erdoğan Washington'da Konuştu,” November 14, 2008.

${ }^{30}$ Sinkaya interview, November 8, 2010.

${ }^{31}$ Pat McDonnell Twair, "Turkish Ambassador Addresses Israel, Egypt, Cyprus, Iran, Other Regional Issues," Washington Report on Middle East Affairs, April 2011, 40-41, http://www.washington-report.org/ home/365/10371-turkish-ambassador-addresses-israel-egypt-cyprus-iran-other-regional-issues.html.

${ }^{32}$ The swap deal required Iran to transport 1,200 kilograms of 3.5 percent-enriched uranium to Turkey in exchange for 20 percent-enriched nuclear fuel to use in a reactor in Tehran that produces medical isotopes.

${ }^{33} \mathrm{Jim}$ Walsh (expert in international security and a research associate at the Massachusetts Institute of Technology), in discussion with the author, November 10, 2010. 
${ }^{34}$ Diego Santos Vieira de Jesus, "Building Trust and Fexibility: A Brazilian View of the Fuel Swap with Iran,'The Washington Quarterly 34, no.2 (2011): 61.

${ }^{35} \mathrm{Jim}$ Walsh, interview, November 10, 2010.

${ }^{36}$ See UN Security Council, Res. 1929.

${ }^{37}$ Interview with high-ranking Turkish diplomat, Ankara, Turkey, October 26, 2010.

${ }^{38}$ Avner Cohen, Israel and the Bomb (Columbia University Press, 1998).

${ }^{39}$ Özgür Özdamar and Nihat Ali Özcan, "Uneasy Neighbors": 112.

${ }^{40}$ Bayram Sinkaya (presentation at Middle East Technical University, Ankara, Turkey, November 23, 2010).

See also, “Ankara Rules Out Competition with Brazil in Efforts on Iran,” Today's Zaman, May 8, 2010.

${ }^{41}$ Sinkaya interview, November 8, 2010.

${ }^{42}$ Interview with high-ranking Turkish diplomat Ankara, Turkey, October 26, 2010.

43 "Iran Verified on Saturday It Is Building Uranium Enrichment Centrifuge Parts at Its Taba Plant West of Tehran," Global Security News (GNS), April 11, 2011.

${ }^{44}$ Kazim Gharib Abadi (Iran's ambassador to Netherlands), in discussion with the author, October 22, 2010.

${ }^{45}$ Ibon Villelabeitia and Tulay Karadeniz, "Iran Says January Nuclear Talks Historical Opportunity,” Reuters

December 24, 2010, http://in.reuters.com/article/2010/12/23/idINIndia-53760920101223;

${ }^{46}$ Henri J. Barkey, "What's Turkey's Role in the Second Round of Iranian Talks?" Carnegie Endowment Publications, January 9, 2011.

${ }^{47}$ Brian Katulis (senior fellow at American Progress), in discussion with the author, December 17, 2011.

${ }^{48}$ Reuters, “After Stuxnet: Iran Says It's Discovered 2nd Cyber Attack,” Jerusalem Post, April 25, 2011, http:/www.jpost.com/IranianThreat/News/Article.aspx?ID=217795\&R=R1.

${ }^{49}$ Nihat Ali Özcan (Economic Policy Research Foundation [TEPAV]), in discussion with the author, November $17,2011$.

${ }^{50}$ Murat Mercan, ([AKP], Eskisehir, the former president of the Council of Europe Parliamentary Assembly [PACE] and the president of Turkish Delegation in theWestern European Union Assembly of Turkish Delegation [WEU]), in discussion with the author, November 22, 2011. This conversation provided insight into Turkish-Iranian relations.

${ }^{51}$ Şaban Kardaş, “Quest for Strategic Autonomy Continues, or How to Make Sense of Turkey’s 'New Wave'," Today's Zaman, December 8, 2011.

52 Ibid.

${ }^{53}$ Nihat Ali Özcan, in discussion with the author, November 17, 2011.

${ }^{54}$ Ibid.

${ }_{55}$ Turkish Undersecretariat for Defense Industries, Savunma Sanayaii Müsteşarlı̆̆ Uzun Menzilli Bölge Hava ve Füze Savunma Sistemi Projesi Bilgi Istek Dokumanı (BID) Alıp Cevap Vereceğini Bildiren Firmalara Ilişkin Duyuru, July 14, 2007. It was announced that the following Turkish, American, Chinese and Israeli firms were putting bids forward for this air missile defense procurement project of the Turkish Undersecretariat for Defense Industries: BOEING (United States), CPMIEC (People's Republic of China), C-TECH (Turkey), FNSS (Turkey), GATE (Turkey), Havelson Teknoloji Radar (Turkey), IAI (İsrael), Lockheed Martin (United States) Milsoft (Turkey), Raytheon (United States), Roketsan (Turkey), ASELSAN (Turkey) and YESAS (Turkey), http://www.ssm.gov.tr/anasayfa/hizli/duyurular/projeDuyurulari/arsiv/2007Arsiv/Sayfalar/ UzunMenzilliBHFSSistPro.aspx.

${ }^{56}$ Tacan Idem (Turkish ambassador, Ankara), in discussion with the author, February 1, 2011.

57 "Strategic Concept for the Defense and Security of the Members of the North Atlantic Treaty Organization," NATO Documents, adopted by Head of States and Governments in Lisbon, November 19, 2010, http:// www.nato.int/lisbon2010/strategic-concept-2010-eng.pdf.

${ }^{58}$ Hasan Femi Kinay (Parliamentarian [AKP], Kütahya. Plan and Budget Commissioner), November 15, 2011.

${ }^{59}$ Ali Akbar Dareini, "Iran Criticizes Turkey over Missile Defense Shield," The Guardian, October 4, 2011.

60 "IRGC Commander: Iran to Target NATO Missile Shield if Attacked," Fars News Agency, November 26,

2011, http://english.farsnews.com/newstext.php?nn=9007274969.

${ }^{61}$ William Tobey (Harvard University), in discussion with the author, April 3, 2011.

${ }^{62}$ Stephen F. Larrabee (United States Air Force, RAND Corporation), in discussion with the author, November 6, 2010 . 
Middle East Policy, Vol. XIX, No. 1, Spring 2012

${ }^{63}$ Arif Keskin (21st Century Think Tank, Ankara Turkey), in discussion with the author, January 26, 2011. See also Muzaffer Kural, Türk Tarıh Kurumu (Ankara), in discussion with the author, June 16, 2011.

${ }^{64}$ Stephen F. Larrabee, in discussion with the author, November 6, 2010.

65 Ibid.

${ }^{66}$ Cole J. Harvey, "From Theory to Reality: The Evolution of Multilateral Assurance of Nuclear Fuel Supply," Nuclear Threat Initiative, last modified March 24, 2011, http://www.nti.org/e_research/e3_fuel_cycle. html; See also Global Nuclear Energy Partnership Strategic Plan, GNEP-167312, Rev. 0, U.S. Department of Energy, January 2007, http://www.fas.org/programs/ssp/_docs/GNEPStratPlanJan07.pdf. This approved British proposal, namely the bond concept, shares many characteristics with the two fuel banks. A recipient state will only be able to participate in the bond if (1) it is a party to the Treaty on the Nonproliferation of Nuclear Weapons (NPT); (2) it has brought into force a comprehensive safeguards agreement; (3) the IAEA has concluded that there has been no diversion of declared nuclear material in that country; and (4) no issues of safeguards implementation are under consideration by the Board of Governors. If the IAEA director general certifies to the supplier state that all four conditions have been met, the supplier is legally committed by the bond to issue the necessary export licenses.

${ }^{67}$ Fred McGoldrick, Matthew Bunn, Martin Malin, and William M. Tobey, Limiting Transfers of Enrichment and Reprocessing Technology: Issues, Constraints, Options, Project on Managing the Atom, Harvard Kennedy School Belfer Center, May 2011.

${ }^{68}$ William H. Tobey (senior fellow, Belfer Center for Science and International Affairs), in discussion with the author, April 3, 2011.

${ }^{69}$ Gareth Evans (Melbourne University), in discussion with the author, April 1, 2011. See also Gareth Evans and Yoriko Kavaguchi, Eliminating Nuclear Threat, Report of International Commission on Nuclear Nonproliferation and Disarmament, 132-147.

${ }^{70}$ Gareth Evans (Melbourne University), in discussion with the author, April 4, 2011. See Gareth Evans, chapter on multilateralization of the fuel cycle in my nuclear commission report, accessible at www.icnnd.org.

${ }^{71}$ Hans Blix (former director of the IAEA and the current head of the advisory board for Arab Emirates Nuclear Program), in interview with the author, July 6, 2011.

${ }^{72}$ Alexander Sotnichenko (St. Petersburg State University), in discussion with the author, April 4, 2011.

${ }^{73}$ Siegfried S. Hecker (Stanford University), in discussion with the author, April 3, 2011.

${ }^{74}$ Mordechai (Moti) Melamud (a research physicist at the Comprehensive Nuclear Test-ban Treaty Organization [CTBTO]), in discussion with the author, March 27, 2011.

${ }^{75}$ Charles D. Ferguson (president of the Federation of the American Scientists), in discussion with the author, May 7, 2011.

${ }^{76}$ William Tobey (Harvard University), in discussion with the author, April 3, 2011.

${ }^{77}$ Elliot Abrams (Council on Foreign Relations), in discussion with the author, November 4, 2010.

${ }^{78}$ Gunter Verheugen (former European Commissioner, Bilkent University, Ankara Turkey), in discussion with the author, November 16, 2011.

${ }^{79}$ Soner Çağaptay (Voice of America), in discussion with the author, November 8, 2011.

${ }^{80}$ Roula Khalaf, "Politics Strokes Fears over Iran Nuclear Plans," Financial Times, November 14, 2011. 